\title{
Choroidal and Ciliary Body Melanoma pT1d TNM Finding v8
}

National Cancer Institute

\section{Source}

National Cancer Institute. Choroidal and Ciliary Body Melanoma pT 1d TNM Finding v8. NCI Thesaurus. Code C140635.

Choroidal and ciliary body melanoma, tumor size category 1 with ciliary body involvement and extraocular extension $5 \mathrm{~mm}$ or less in largest diameter. (from AJCC 8th Ed.) 